\title{
PERANCANGAN SITANI SEBAGAI MEDIA INFORMASI BAGI PETANI
}

\author{
Eko Harry Pratisto \\ Diploma 3 Teknik Informatika \\ Universitas Sebelas Maret \\ email: ekoharry@staff.uns.ac.id \\ Arif Budi Waluyo \\ Diploma 3 Teknik Informatika \\ Universitas Sebelas Maret
}

\begin{abstract}
ABSTRAK
Bidang pertanian merupakan salah satu sumber mata pencaharian masyarakat di Karesidenan Surakarta. Akan tetapi masih ada beberapa permasalahan-permasalahan dibidang pertanian yang terjadi, seperti : terjadinya kelangkaan barang-barang kebutuhan pertanian, sulitnya memperoleh informasi kegiatan penyuluhan, dan kesulitan untuk menjual hasil panen pada masa panen karena permainan harga dari tengkulak.

Aplikasi SITANI dibuat menggunakan metode waterfall dengan bahasa pemrograman java dan tool android studio. Perancangan yang digunakan dalam pembuatan aplikasi ini antara lain : tabel kebutuhan fungsional, use case diagram, ERD, activity diagram, dan desain interface. Untuk pengujian aplikasi menggunakan kuisioner.

Hasil dari penelitian ini adalah terciptanya aplikasi SITANI berbasis android dengan modul pemasangan iklan, informasi kegiatan penyuluhan, dan pemesanan barang.
\end{abstract}

Kata kunci: Android, Aplikasi, Penjualan, Pertanian, Informasi

\begin{abstract}
Agriculture is one source of livelihood of people in Surakarta. However, there are some problems that occur in agriculture, such as: the shortage of agricultural goods, the difficulty of obtaining workshop activities information, and difficulty to sell crops at harvest periode for the arragement price from middlemen.

SITANI application is develop using waterfall method and built using Java programming language with tool Android Studio. The design includes table of functional requirements, use case diagram, ERD, activity diagrams, and interface design. Application testing is done using quistionnaire.

The results of this research is the creation of android-based application with modules SITANI advertsement, workshop activities information, and ordering goods.
\end{abstract}

Keywords: Agriculture, Android, Application, Information, Market

\section{PENDAHULUAN \\ 1.1. Latar Belakang}

Bidang pertanian merupakan salah satu sumber mata pencaharian masyarakat di Karesidenan Surakarta. Luas penggunaan lahan sawah pada tahun 2015 sekitar 20.643 hektar atau sekitar 50\% dari total lahan kabupaten Sukoharjo[1]. Di Kabupaten Sukoharjo masih terjadi beberapa permasalahan di bidang pertanian, diantaranya kelangkaan terhadap barang kebutuhan pertanian dalam kondisi-kondisi tertentu, akibatnya banyak terjadi ketidaksediaan barang-barang kebutuhan pertanian di beberapa usaha dagang, sehingga masyarakat kesulitan untuk meperoleh barang kebutuhan pertanian. Para petani sulit untuk memperoleh informasi kegiatan penyuluhan yang bermanfaat dalam mengetahui tentang teknik- teknik pertanian yang terbaru. Masalah lain adalah permainan harga dari tengkulak pada masa panen sehingga menyulitkan untuk menjual hasil pertanian.

Untuk mengatasi permasalahan tersebut maka dikembangkan aplikasi untuk memudahkan petani dalam menjual hasil panen, mendapatkan kebutuhan-kebutuhan pertanian, dan mendapatkan informasi tentang kegiatan penyuluhan untuk meningkatkan hasil pertanian. 


\subsection{Landasan Teori}

\subsubsection{Metode Waterfall}

Model waterfall adalah suatu proses pengembangan perangkat lunak berurutan, dimana kemajuan dipandang sebagai terus mengalir kebawah (seperti air terjun) melewati fase-fase pencenaan, pemodelan, implementasi, dan pengujian. Terlihat pada Gambar 1, metode waterfall memiliki beberapa tahapan yang runtut: requirement, design, implementation, verification, dan maintenance[2].

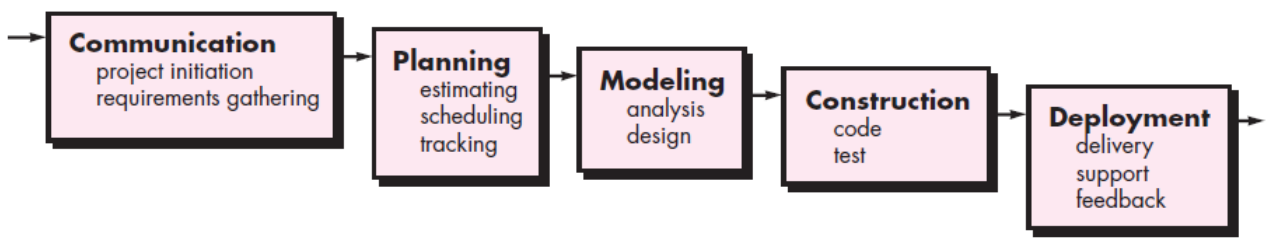

Gambar 1. Metode waterfall[2]

\subsubsection{Aplikasi Android}

Menurut [3] aplikasi mobile adalah sebutan untuk aplikasi yang berjalan di mobile device. Dengan menggunakan aplikasi mobile, dapat dengan mudah melakukan berbagaii macam aktifitas mulai dari hiburan, berjualan, belajar, mengerjakan pekerjaan kantor, browsing dan lain sebagainya. Android merupakan sistem operasi Linux yang bersifat terbuka (open source) dan dirancang untuk perangkat seluler layar sentuh seperti smartphone dan komputer tablet. Android dikembangkan oleh Android, Inc.,dengan dukungan finansial dari Google yang kemudian dibeli pada tahun 2005. Tampilan Android didasarkan pada manipulasi langsung, menggunakan masukan sentuh yang serupa dengan tindakan di dunia nyata, seperti mengesek, mengetuk, mencubit, dan membalikkan cubitan untuk memanipulasi obyek di layar[4]. Aplikasi Android dapat dikembangkan menggunakan Android Studio yang merupakan IDE yang bisa digunakan untuk pengembangan aplikasi Android, dan dikembangkan oleh Google. Android Studio merupakan pengembangan dari Eclipse IDE, dan dibuat berdasarkan IDE Java populer, yaitu IntelliJ IDEA. Sebagai pengembangan dari Eclipse, Android Studio mempunyai banyak fitur-fitur baru dibandingkan dengan Eclipse IDE. Berbeda dengan Eclipse yang menggunakan ADT, Android Studio menggunakan Gradle sebagai build environment [5].

\subsubsection{Use Case}

Use case diagram merupakan diagram yang menyajikan interaksi antara use case dan aktor. Aktor dapat berupa orang, peralatan, atau sistem lain yang berinteraksi dengan sistem yang sedang dibangun. Use case menggambarkan fungsionalitas sistem atau persyaratan-persyaratan yang harus dipenuhi sistem dari pandangan pemakai[6].

Diagram use case digunakan untuk mengetahui fungsi apa saja yang ada di dalam sebuah sistem dan siapa saja yang berhak menggunakan fungsi-fungsi tersebut. Terdapat beberapa simbol dalam menggambarkan diagram use case, yaitu use cases, aktor dan relasi. Hal yang perlu diingat mengenai diagram use case adalah diagram use case bukan menggambarkan tampilan antarmuka (user interface), arsitektur dari sistem, kebutuhan nonfungsional, dan tujuan performansi. Sedangkan untuk penamaan use cases adalah nama didefinisikan paling sedederhana, dapat dipahami dan menggunakan kata kerja[7].

\subsubsection{Entity Relationship Diagram}

Entity Relationship Diagram adalah diagram yang berisi komponen-komponen himpunan entitas dan himpunan relasi yang masing-masing dilengkapi dengan atribut-atribut yang merepresentasikan seluruh fakta dari 'dunia nyata' yang ditinjau. Ada dua komponen penyusun ERD, yaitu entity atau entitas dan relation atau relasi. Entity atau entitas merupakan individu yang mewakili sesuatu yang nyata dan dapat dibedakan dari sesuatu yang lain. Sedangkan relasi menunjukan adanya hubungan di antara sejumlah entitas yang berasal dari himpunan entitas yang berbeda[8].

\section{METODOLOGI PENELITIAN}

Metodologi penelitian yang digunakan meliputi:

a. Pengumpulan Data

1) Observasi

Mengumpulkan data-data terkait dengan informasi barang-barang kebutuhan pertanian dan kegiatan penyuluhan.

2) Wawancara

Melakukan wawancara terhadap calon pengguna yaitu petani di kabupaten Sukoharjo dan mengumpulkan data-data terkait dengan kebutuhan pertanian dengan pemilik Unit Dagang.

b. Pembuatan Aplikasi 
1) Perancangan aplikasi

Merancang aplikasi dengan menggunakan Unified Modelling Language (UML). Mulai dari use case diagram, activity diagram, dan sequence diagram.

2) Implementasi sistem

Melakukan pembuatan aplikasi dengan Android Studio berdasarkan rancangan yang telah dibuat pada tahap sebelumnya.

c. Pengujian Aplikasi

Pengujian berfokus pada fungsional perangkat lunak yang dibangun. Ada beberapa metode dalam pengujian sistem, metode yang diambil dalam pengujian ini adalah pengujian kompatibilitas aplikasi di beberapa device android.

\section{HASIL DAN PEMBAHASAN}

\subsection{Proses bisnis}

Berdasarkan dari tahap observasi dan wawancara yang dilakukan maka dapat digambarkan proses bisnis dari aplikasi seperti pada Gambar 2.

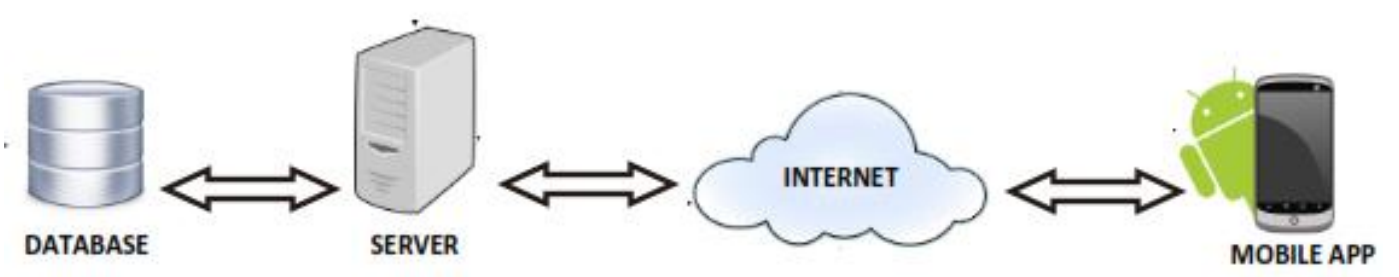

Gambar 2. Proses bisnis aplikasi Sitani

Aplikasi yang dibangun untuk menerima dan mengirim data dari dan ke server adalah aplikasi mobile berbasis Android, yang menyediakan site untuk tiga pengguna diantaranya global user/pengunjung, member dan pemilik Usaha Dagang (UD). Secara umum, proses bisnis aplikasi SITANI adalah sebagai berikut:

a. Global user/pengunjung melihat informasi kegiatan penyuluhan, data iklan, barang yang dijual UD, dan peta lokasi.

b. Member melihat informasi kegiatan penyuluhan, data iklan, barang yang dijual UD, peta lokasi, dan melakukan pemesanan barang.

c. Member mengelola data iklan dan informasi kegiatan penyuluhan.

d. Pemilik UD melihat informasi kegiatan penyuluhan, data iklan, barang yang dijual UD, peta lokasi, dan melakukan pemesanan barang.

e. Pemilik UD mengelola data iklan, data informasi kegiatan penyuluhan, data barang, dan data pesanan barang.

f. Admin menyetujui data iklan atau data informasi kegiatan penyuluhan yang ditulis member.

g. Admin memverifikasi pendaftaran UD.

\subsection{Use case diagram}

Use Case Diagram aplikasi berbasis android terdiri dari empat aktor. Aktor yang pertama adalah global user/pengunjung, aktor yang kedua adalah member, aktor yang ketiga adalah pemilik UD, dan aktor yang keempat adalah admin. member, pemilik UD, dan admin adalah user yang sudah login ke dalam aplikasi. Use case diagram untuk level user pengunjung/global user dan admin dapat dilihat pada Gambar 3, sedangkan use case diagram untuk level user member dan pemilik UD dapat dilihat pada Gambar 4. 
Indonesian Journal of Applied Informatics, Vol. 1 No. 1, November 2016 ISSN: 2548-3846

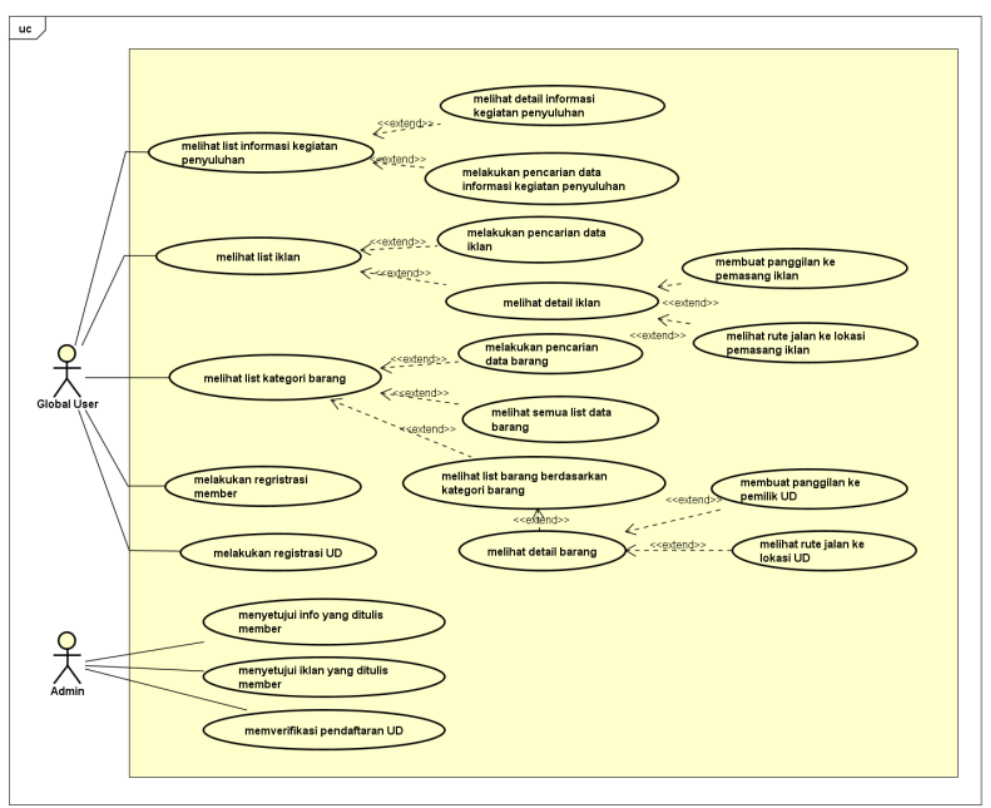

Gambar 3. Use case diagram untuk aktor pengujung dan admin

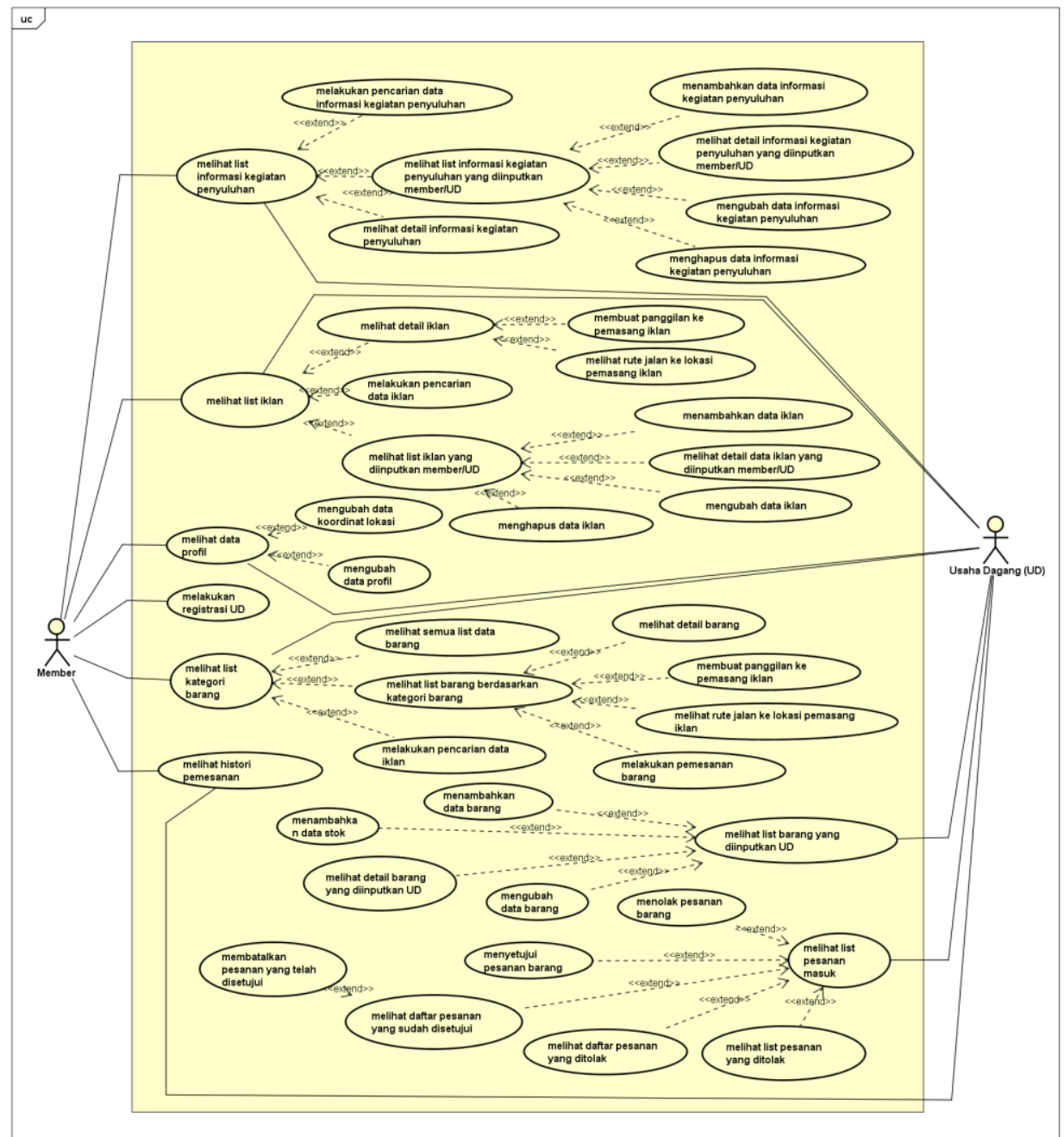

Gambar 4. Use case diagram untuk aktor member dan pemilik UD 
Hasil pengembangan dari tahap analisa kemudian dikembangkan menjadi aplikasi berdasarkan functional requirement, desain antar muka, dan dokumen UML. Aplikasi dikembangkan dengan membuat backend berupa sistem informasi dengan menggunakan database MySQL. Untuk aplikasi Android dikembangkan dengan menggunakan Android Studio. Hasil dari pengembangan aplikasi Android dapat dilihat pada Gambar 5.

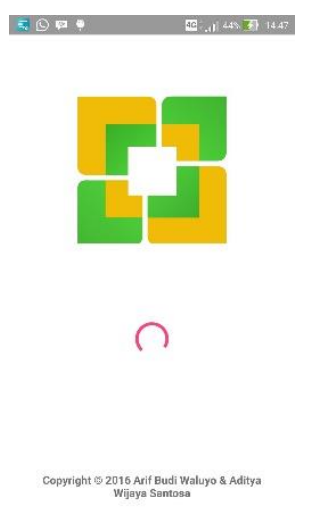

(a) Halaman utama

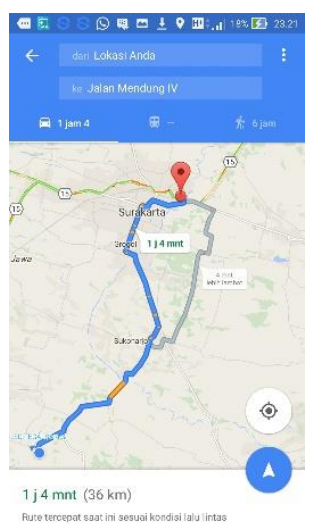

(e) Peta lokasi penjual

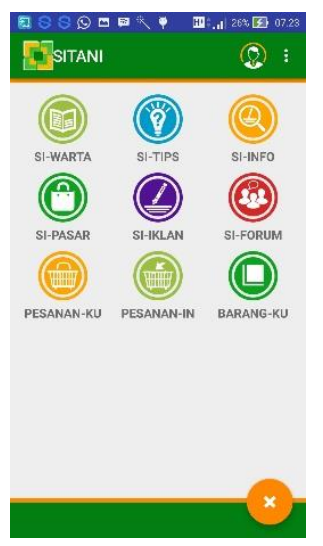

(b) Menu utama

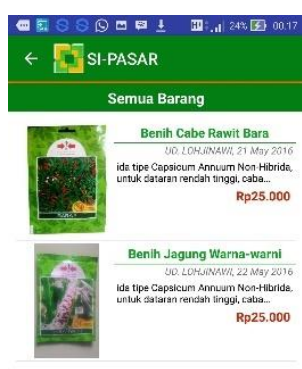

(f) Halaman SI Pasar

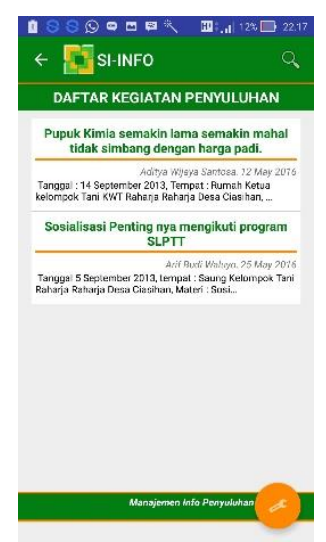

(c) Daftar penyuluhan

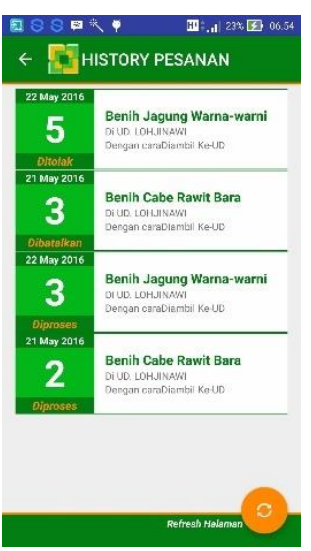

(g) Histori pemesanan

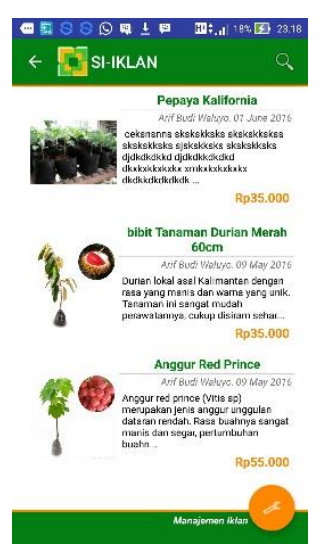

(d) Halaman iklan

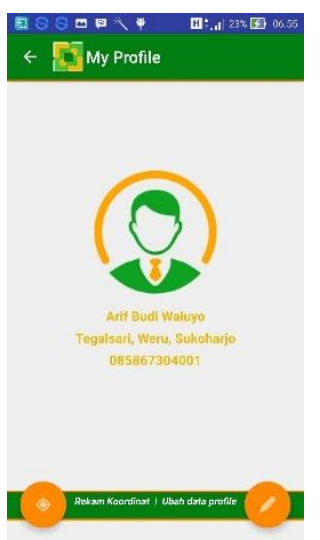

(h) Profil user

Gambar 5. Tampilan antarmuka aplikasi SITANI

Tahap berikutnya adalah pengujian pada pengguna dimana aplikasi diujikan kepada 30 responden. Kuisioner dirancang dengan menggunakan skala Likert dengan 5 pilihan jawaban yaitu Sangat Tidak Setuju (1), Tidak Setuju (2), Cukup (3), Setuju (4) dan Sangat Setuju (5). Hasil kuisioner dapat dilihat pada Tabel 1.

Tabel 1. Hasil pengujian berdasarkan kuisioner

\begin{tabular}{llllllc}
\hline \multirow{2}{*}{ No } & \multicolumn{1}{c}{ Pernyataan } & \multicolumn{4}{c}{$\begin{array}{c}\text { Prosentase responden berdasarkan } \\
\text { pilihan (\%) }\end{array}$} \\
\cline { 3 - 7 } & \multicolumn{1}{c}{$\mathbf{1}$} & $\mathbf{2}$ & $\mathbf{3}$ & $\mathbf{4}$ & $\mathbf{5}$ \\
\hline 1 & Tampilan aplikasi mudah dipahami & 0 & 0 & 19.4 & 67.7 & 12.9 \\
\hline 2 & $\begin{array}{l}\text { Informasi yang disajikan sesuai dengan ekspektasi } \\
\text { pengguna }\end{array}$ & 0 & 0 & 16.4 & 64.5 & 19.4 \\
\hline 3 & Fitur pada aplikasi sesuai dengan fungsinya & 0 & 0 & 12.9 & 64.5 & 22.6 \\
\hline 4 & $\begin{array}{l}\text { Memesan produk lebih mudah melalui aplikasi } \\
\text { dibandingkan datang langsung ke UD }\end{array}$ & 0 & 3.2 & 6.5 & 67.7 & 22.6 \\
\hline
\end{tabular}

Berdasarkan hasil kuisioner mengenai penggunaan terhadap aplikasi SITANI yang diberikan kepada responden dapat dirangkum bahwa secara keseluruhan aplikasi telah memenuhi harapan pengguna. 


\section{KESIMPULAN}

Aplikasi SITANI berhasil dibuat untuk memudahkan petanai dalam mencari informasi terkait pelatihan, penyuluhan serta penjualan terkait pertanian. Dari hasil kuisioner yang diberikan pada 30 responden, sekitar lebih dari $60 \%$ setuju bahwa aplikasi SITANI memiliki tampilan yang mudah dipahami, informasi sesuai dengan ekspektasi pengguna, fitur sudah sesuai dengan fungsinya dan kemudahan dalam memesan produk jika dibandingkan datang langsung ke Usaha Dagang.

Untuk pengembangan aplikasi berikutnya diharapkan dapat ditambahkan forum diskusi serta perbaikan pada fitur pengiriman barang hasil pertanian.

\section{DAFTAR PUSTAKA}

1. Badan Pusat Statistik Kabupaten Sukoharjo. Luas Penggunaan Lahan menurut Kecamatan di Kabupaten Sukoharjo tahun 2015 [Internet]. 2017 [cited 2017 May 14]. Available from:

https://sukoharjokab.bps.go.id/LinkTableDinamis/view/id/31

2. Pressman RS. Software Engineering: A Practitioner's Approach. 6th ed. New York: Boston; 2005. (McGraw-Hill higher education).

3. Purnama R. Mari Mengenal J2ME : java 2 Micro Edition. Jakarta: Prestasi Pustaka; 2010.

4. Salbino S. Buku Pintar Gadget Android untuk Pemula: untuk pemula. Budiman H, editor. Jakarta: Lembar Langit Indonesia; 2013.

5. Google. Mengenal Android Studio [Internet]. [cited 2017 May 15]. Available from: https://developer.android.com/studio/intro/index.html?hl=id

6. Nugroho A. Rekayasa Perangkat Lunak Berorientasi Objek dengan Metode USDP. Oktaviani, editor. Yogyakarta: Andi Offset; 2010. 319 p.

7. Kendall KE, Kendall JE. Systems Analysis and Design. Pearson Prentice Hall; 2011.

8. Kusrini. strategi perancangan dan pengelolaan basis data. Yogyakarta: Penerbit Andi; 2007. 103 p. 